INTERNATIONAL

FOOD POLICY

RESEARCH

INSTITUTE

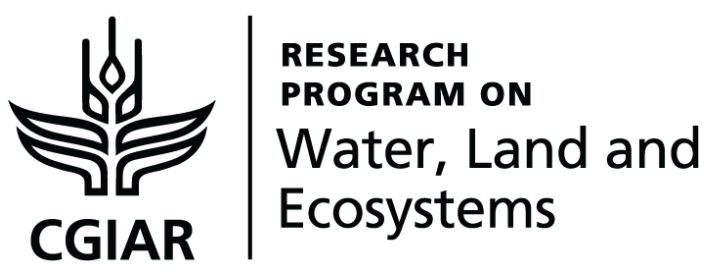

IFPRI Discussion Paper 02025

May 2021

\title{
Women and Small-Scale Irrigation \\ A Review of the Factors Influencing Gendered Patterns \\ of Participation and Benefits
}

Elizabeth Bryan

Nicole Lefore

Environment and Production Technology Division 


\section{INTERNATIONAL FOOD POLICY RESEARCH INSTITUTE}

The International Food Policy Research Institute (IFPRI), a CGIAR Research Center established in 1975, provides research-based policy solutions to sustainably reduce poverty and end hunger and malnutrition. IFPRI's strategic research aims to foster a climate-resilient and sustainable food supply; promote healthy diets and nutrition for all; build inclusive and efficient markets, trade systems, and food industries; transform agricultural and rural economies; and strengthen institutions and governance. Gender is integrated in all the Institute's work. Partnerships, communications, capacity strengthening, and data and knowledge management are essential components to translate IFPRI's research from action to impact. The Institute's regional and country programs play a critical role in responding to demand for food policy research and in delivering holistic support for country-led development. IFPRI collaborates with partners around the world.

\section{AUTHORS}

Elizabeth Bryan (e.bryan@cgiar.org) is a Senior Scientist in the Environment and Production Technology Division of the International Food Policy Research Institute (IFPRI), Washington, DC.

Nicole Lefore (nicole.lefore@ag.tamu.edu) is Director of the Feed the Future Innovation Lab for Small Scale Irrigation at the Norman Borlaug Institute for International Agriculture and Development at Texas A\&M University, College Station, TX.

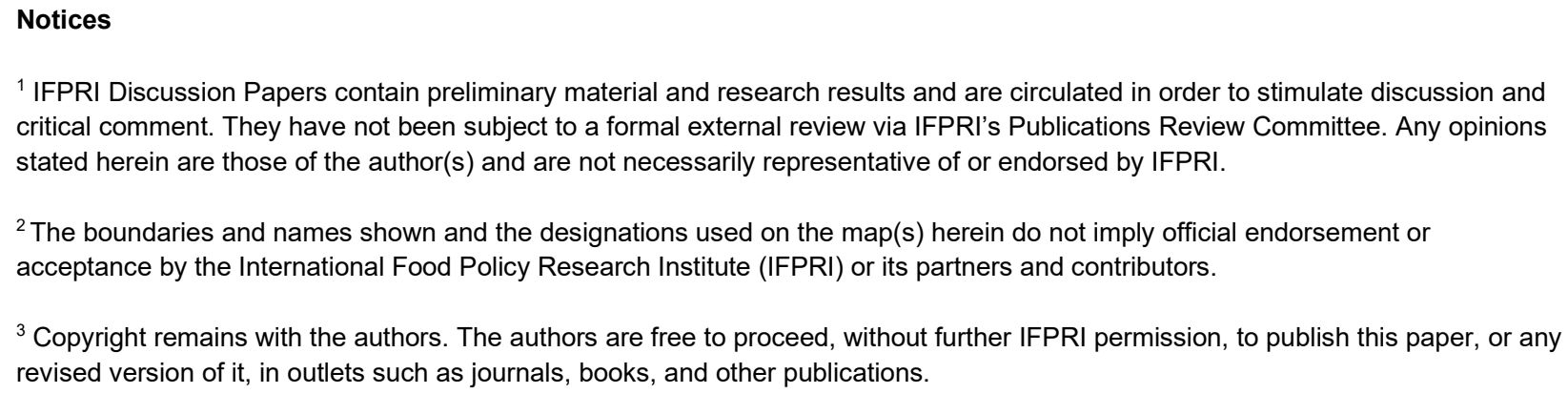




\section{Contents}

ABSTRACT

ACKNOWLEDGMENTS iv

1. Introduction 1

2. Conceptual Framework 4

3. Application of the Framework to Case Studies by Type of Irrigation 11

3.1. Communal Schemes for Small-Scale Irrigation 12

3.1.1. Resources 13

3.1.2. Agency 14

3.1.3. Benefits 15

3.2. Household-Level Irrigation 16

3.2.1. Resources 18

3.2.2. Agency 20

3.2.3. Benefits 21

3.3. Group-Based Irrigation 25

3.3.1. Resources $\quad 25$

3.3.2. Agency 26

3.3.3. Benefits 26

4. Achieving Development Outcomes through Women's Participation in Small-Scale Irrigation 28

5. Conclusions 31

$\begin{array}{ll}\text { REFERENCES } & 34\end{array}$

\section{Tables}

Table 1: Types of Irrigation by Scale.

Figures

Figure 1: Framework for Small-Scale Irrigation and Women's Empowerment. 


\begin{abstract}
Small-scale irrigation is expanding rapidly in parts of the world, especially sub-Saharan Africa, offering smallholder farmers an opportunity to improve their livelihoods, diets, and resilience to climate change among other benefits. Growing research focuses on the potential for small-scale irrigation to offer a pathway for women's empowerment, yet the factors conditioning the relationship between small-scale irrigation and women's empowerment are not well understood. The evidence tends to be scattered across context-specific case studies that focus on targeted outcomes, without distinguishing between technology types, scales, or approaches to irrigation systems or technologies. This paper synthesizes the issues related to gender and small-scale irrigation using a conceptual framework that highlights the linkages between elements of women's empowerment and small-scale irrigation. Because gendered dynamics with smallscale irrigation play out differently depending on the scale of irrigation and the technologies used, this paper applies the framework to examine case studies across a typology of small-scale irrigation systems. The case studies cover a range of farming and livelihood systems in which women's roles and gender relations vary, highlighting the importance of the opportunity structure or context in which irrigation takes place. This paper then draws lessons on the various ways in which small-scale irrigation, gender relations, and women's empowerment interact and highlights areas where research gaps remain.
\end{abstract}

Keywords: gender, women's empowerment, small-scale irrigation 


\section{ACKNOWLEDGMENTS}

This work was carried out under the CGIAR Research Program on Water, Land and Ecosystems (WLE) and supported by Funders contributing to the CGIAR Trust Fund, including Australian Centre for International Agricultural Research (ACIAR), United Kingdom: Department for International Development (DFID), The Netherlands: Directorate-General for International Cooperation (DGIS), Swiss Agency for Development Cooperation (SDC), Swedish International Development Cooperation Agency (Sida) and other partners found at wle.cgiar.org/donors. WLE is led by the International Water Management Institute (IWMI) with 12 other partners. This publication was also partly made possible through support provided by the Feed the Future Innovation Lab for Small Scale Irrigation through the U.S. Agency for International Development, under the terms of Contract No. AID-OAA-A-13-0005. Content may not reflect official opinions of these organizations. The authors also want to thank Jennie Barron, Claudia Ringler and Ruth Meinzen-Dick for initiating and providing early direction and input on this review. 


\section{INTRODUCTION}

Small-scale irrigation has gained attention of policy makers and development institutions as an important practice for increasing yields and profits of smallholder producers in developing countries (Xie et al. 2014, Giordano and de Fraiture 2014, Burney, Naylor, and Postel 2013; You et al. 2011) and for mitigating the risks of climate change (Nangia and Oweis 2016; Malabo Montpellier Panel 2018). Already widely adopted across much of South Asia (Barker and Molle 2004), recent research documents an increase in the practice throughout sub-Saharan Africa (SSA) (Woodhouse et al. 2017, Beekman, Veldwisch, and Bolding 2014). In addition, research points to the potential for further expansion in the region to increase the profitability of agriculture under climate change, while also improving food security and nutrition outcomes (Xie et al. 2018, Passarelli et al. 2018, Xie et al. 2014, Giordano and de Fraiture 2014, Burney, Naylor, and Postel 2013; You et al. 2011). Small-scale irrigation can be defined as irrigation that farmers control themselves for cultivating small plots of land, using technologies and systems which they operate and maintain at the household level or in small groups or communities. While small-scale irrigation is expanding and offers potential for improved livelihoods and economic growth generally, the sub-sector requires greater scrutiny to begin to assess the gendered patterns of participation and benefits.

New research suggests that small-scale irrigation may contribute to a wider set of development goals beyond just increasing crop productivity and incomes. These include expanding employment opportunities, increasing climate resilience of farming, improving food security and nutrition, as well as providing opportunities for women's empowerment (Bryan and Mekonnen 2021; Passarelli et al. 2018; Adam et al. 2016; Alaofè et al. 2016; Burney and Naylor 2012). The evidence tends to be scattered across context-specific case studies that focus on targeted outcomes, without distinguishing between technology types, scales, or approaches to irrigation systems or technologies. The outcomes of small-scale irrigation interventions often depend on these and other factors - including characteristics of the social, economic, 
and agro-ecological context. The literature reflects the complex linkages and multiple factors between irrigation and development outcomes, which makes analysis of gender particularly challenging. Early research on women in irrigated agriculture focused largely on gendered access to and roles in large public irrigation schemes. This research demonstrated how gender relations influenced irrigation investments and the development of formal and informal irrigation institutions that in turn, often constrained opportunities for women to participate in and benefit from the schemes (Padmaja et al. 2019, Lefore, Weight, and Mukhamedova. 2017, Nkhoma and Kayira 2016). More recently, studies are examining gender dynamics and small-scale irrigation with important contributions from the CGIAR. This literature examines how gender relations at the household level influence adoption and use patterns, and the distribution of costs and benefits across different members of the household, which has broader implications as an increasing number of households adopt technologies for small-scale irrigation throughout SSA and other parts of the world. Gender dynamics at the household level are still strongly influenced by the socio-economic context that defines gender roles in farming.

While this paper focuses primarily on gender, other intersectional characteristics of men and women farmers within the same context, such as their wealth, cast, age, education, marital status and other identities, also shape the distribution of resources and livelihood roles thereby conditioning opportunities for uptake of irrigation and outcomes. For example, in parts of South Asia, including Bangladesh, India, and Pakistan, landless women and women from poorer households tend to be more involved in agriculture — either by working as wage laborers or on family plots — while women from wealthier households tend to be less engaged in agricultural work (Shah and Memon. 2014). Even among women working in agriculture, caste plays a strong role in the extent to which women can participate in water management decisions at the community level (Ahmed 2014). We acknowledge these intersectional factors, but do not include these in this analysis. This paper synthesizes the issues related to gender and small-scale irrigation, including gendered patterns of adoption and use, the distribution of costs and benefits, and the influence of these patterns on development outcomes. These issues play out differently across different small-scale irrigation systems (from household to communal schemes), with different 
irrigation technologies, and across different farming and livelihood systems in which women's roles and gender relations vary widely. Much of the research to date focuses on individual case studies where specific irrigation interventions or technologies or schemes are examined. This paper draws lessons from case studies from a range of contexts in which different irrigation systems and technologies are applied to begin to better understand the various ways in which small-scale irrigation, gender relations, and women's empowerment interact. With an overview of the existing research, we then highlight areas where research gaps remain. 


\section{CONCEPTUAL FRAMEWORK}

The literature on gender and small-scale irrigation consists mostly of disparate case studies of different small-scale irrigation interventions from different local contexts, as noted above. Each covers different aspects of women's empowerment, such as women's ability to adopt small-scale irrigation and/or the benefits they may receive in terms of control over income, decision-making, among others. Women's empowerment is a complex process that plays out differently in different contexts, which means that not all aspects are necessarily considered across the various case studies on the gendered dimensions of small-scale irrigation. Thus, we develop a conceptual framework to provide a conceptual picture of the key elements and connections between small-scale irrigation and women's empowerment. We then use this framework to systematically examine the patterns across cases in terms of the relationship between small-scale irrigation and the various elements of women's empowerment. This approach also helps to highlight evidence gaps and enables us to draw lessons for future investments and intervention approaches.

Women's empowerment is multi-dimensional, and is often conceived as both an outcome (having greater access to and control over resources and decision-making ability) and a process of change (the process of expanding people's freedom to act and capacity to make choices) (Alsop et al. 2006, Datta and Kornberg 2002, Stern et al. 2005, Nussbaum 2000, and Kabeer 1999, 2001). Power relations at multiple scales are fundamental to understanding empowerment. Empowerment often includes a relational increase in the forms of power, including: "power to" (the ability and freedom to make decisions that achieve goals), "power with" (achieving shared interests through collective action), "power within" (an individual's sense of freedom from restriction, self-respect, and self-efficacy), and "power over" (control over others, regarded as a negative form of coercive power) (Rowlands 1997, Mosedale 2005, Datta and Kornberg 2002, and Deshmukh-Ranadive 2005). Other frameworks of empowerment describe the opportunity structure (broader social and political context in which actors pursue their interests), agency (individual and collective ability to utilize assets and capacities to make choices), and the interaction 
between these as determinants of empowerment (Alsop et al. 2006, Narayan 2005, and Petesch et al. 2005). While these concepts can be applied across a variety of contexts and settings, frameworks should allow flexibility to integrate emic understandings of empowerment (Meinzen-Dick et al 2019, Mason 2005, and Narayan 2005).

The framework used for this study acknowledges and builds on the existing approaches and allows for an iterative process of women's empowerment. This framework enables us to consider the process and entry points through which women improve their ability to make strategic life choices (agency) by utilizing resources (e.g. assets and capacities), leading to improvements in well-being outcomes (achievements), such as food and nutrition security, and/or economic and social status (Bryan and Garner 2020; Meinzen-Dick et al. 2019; Kabeer 1999). Agency is defined here as an individual's ability and freedom to make decisions that achieve goals (instrumental agency), their ability to achieve shared interests through collective action (collective agency), their internal sense of freedom from restriction, self-respect, and self-efficacy (intrinsic agency). Resources expand the range of opportunities for women to make strategic life choices. Similarly, women need agency to be able to access and control resources. This is illustrated by the two-way arrow between resources and agency. This interaction then produces achievements (or lack of achievements) including changes in well-being outcomes for better or worse. This process is iterative, whereby well-being outcomes influence women's access to and control over resources and their level of agency, as shown by the arrows feeding back into these components. The opportunity structure influences all of these components, such as the distribution of resources, the ways in which women exercise agency, and the well-being outcomes they are able to achieve. 


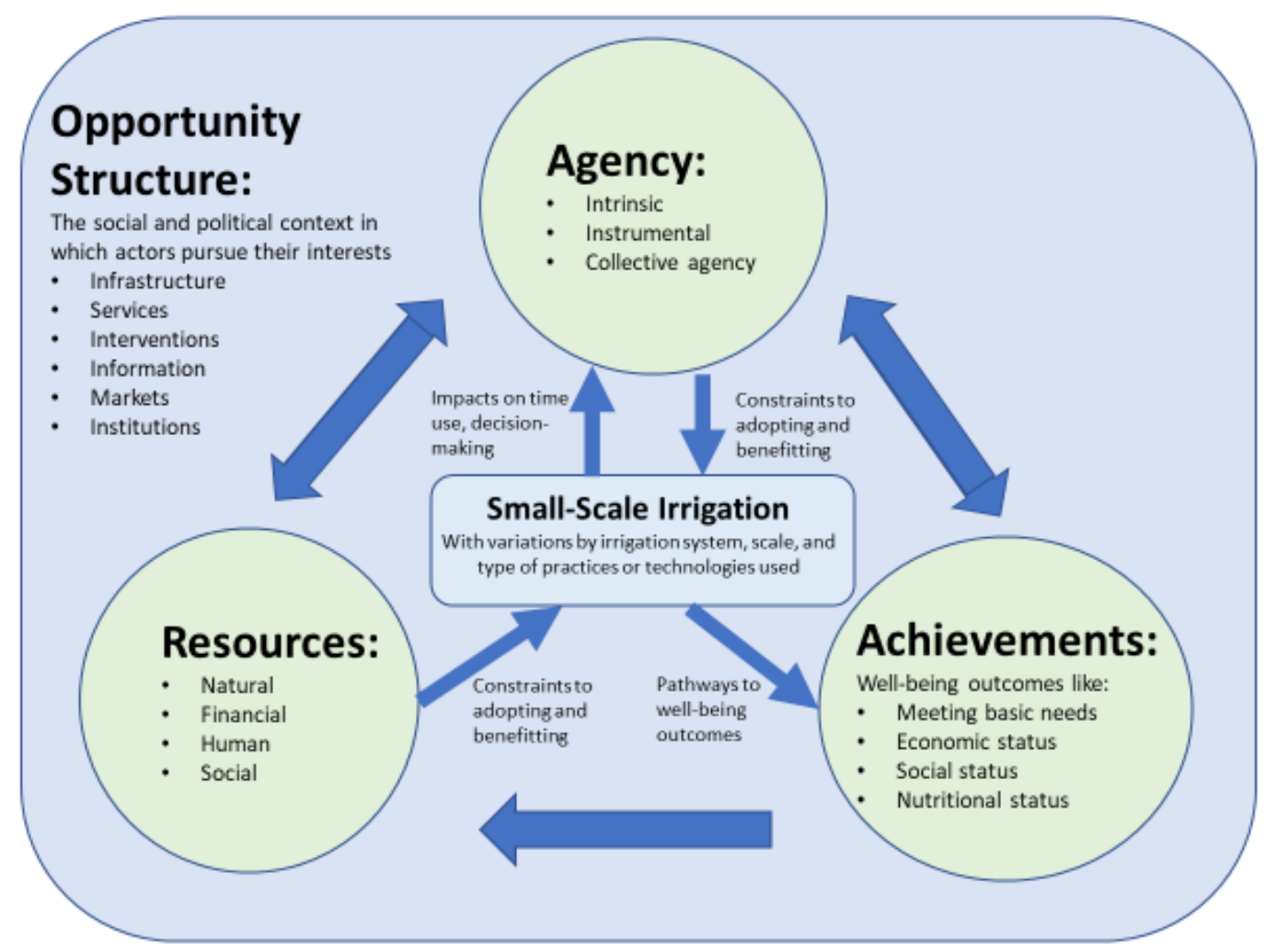

Figure 1: Framework for Small-Scale Irrigation and Women's Empowerment Source: Bryan and Garner 2020 (Adapted from Meinzen-Dick et al. 2019 and Kabeer 1999).

This framework builds on previous approaches in that it places small-scale irrigation into the interaction with and between the components of women's empowerment (resources, agency, and achievements). Small-scale irrigation is shown to have a two-way relationship with the dimensions of empowerment, whereby empowerment influences uptake of irrigation and irrigation also affects changes in empowerment (Figure 1). That is, women's ability to adopt and use small-scale irrigation depends on: 1) their access to productive resources, like land, water and other agricultural inputs, 2) their ability to exercise various types of agency (intrinsic, instrumental and collective), and 3) the institutional environment (or opportunity structure) that governs their behavior within different gendered farming and livelihood systems (Bryan and Garner 2020). Once adopted, small-scale irrigation can increase well-being achievements through several pathways, such as changes in income, changes in food security, and changes in women's empowerment. The opportunity structure, defined as the social, political and institutional context in which different actors pursue their interests (Alsop et al. 2006, Narayan 2005, and 
Petesch et al. 2005), determines the ways in which these relationships play out in a local context by influencing the distribution of resources, the ways in which women can exercise agency, and the wellbeing outcomes they are able to achieve through irrigation.

The opportunity structure shapes the degree and nature in which women participate in and benefit from small-scale irrigation. It consists of the formal and informal rules in society that govern human interaction and power dynamics, including policies, laws, and investments, organizations and program interventions, infrastructure, services, and informal social and cultural norms of behavior. In other words, the opportunity structure goes beyond institutions to consider the broader context in which farming systems are based, which shapes the gender dimensions of these systems in terms of resources, agency, and achievements.

An important part of the opportunity structure is the socio-cultural norms that define men's and women's roles within gendered farming systems. Van Koppen and Hussain (2007) describe two basic types of gendered farming systems — dual-farming vs. male-dominated farming systems - that shape women's water needs and interests as well as the extent and nature in which women participate in and benefit from irrigation. In male-dominated farming systems, women's role in agriculture is not widely recognized or appreciated in society and women tend to be excluded from production and irrigation decisions, face social taboos that prevent them from engaging in irrigation activities, and subject to men's control over the factors of production, including women's own labor (Van Koppen and Hussain 2007). In dual-farming systems, women have somewhat greater ability to adopt and benefit from small-scale irrigation; the potential productivity increases and livelihood improvements from addressing gender gaps in production (i.e. in access to inputs, resources, information, technologies, services, and markets) are great (ibid). Even within these two basic types of gendered farming systems, there is variation in the roles men and women play and in the constraints women face related to factors that shape the specific opportunity structure.

Similarly, social norms also influence the extent to which women can exercise agency to participate in and benefit from small-scale irrigation. In many contexts, women lack decision-making 
authority within the household and community spaces to successfully negotiate for resources and provide input into farming decisions, including the development of irrigation schemes or arrangements and the adoption and use of irrigation technologies in ways that benefit them. For example, women often have less influence over decisions related to the use of irrigated crops or the spending of income from the sale of irrigated crops (Theis et al. 2018). Women may also have more limited mobility or ability to participate in group-based activities, which can further limit their ability to adopt and benefit from small-scale irrigation.

The opportunity structure also shapes access to essential resources for irrigation, such as land and water. Access to water for irrigation is often conditioned on access to land, and when women do not inherit land, their ability to participate in and benefit from irrigation activities depends on men granting them access to irrigable land (Bryan and Garner 2020, Imburgia 2019). In patrilineal societies, women have more difficulty in gaining access to land, whereas in matrilineal societies women can benefit from greater access to and control over land. That said, inheritance norms vary by community within the same country and society. In places where joint rights to land are recognized, women's knowledge of their rights matters, as demonstrated by a study from Ethiopia (Kumar and Quisumbing 2015). In Pakistan, women's inheritance rights are not always recognized which leads to men's de facto control over land (and water) (Shah and Memon 2014). Even in matrilineal societies where women's rights to land are nominally stronger, patriarchal dominance remains the norm, whereby men may still control decisions about land use, farming, the allocation of labor, and income (Djurfeldt et al. 2018).

The gender-sensitivity of policies, investments, and interventions for small-scale irrigation also influences the extent to which women participate in and benefit from various systems for small-scale irrigation. For example, investments in water infrastructure at multiple scales, such as dams, irrigation schemes, and tubewells, may change land and water use patterns and use rights in ways that may negatively affect women by not meeting their specific land and water needs or by negatively affecting their labor burden (Mitra and Rao 2019, Nkhoma and Kayira 2016). That is, policies, investments, and interventions are important components of the opportunity structure that shape the design and 
development of systems for small-scale irrigation and also determine the types of technology and finance available to farmers.

The institutional structures associated with investments in irrigation infrastructure and the spread of irrigation technologies also influence whether or not women and other resource-poor farmers have or can obtain secure rights to land, water, and irrigation infrastructure (Meinzen-Dick 2014). Notably, women and other marginalized farmers' meaningful participation in the development and operation of irrigation interventions and in community groups for water management conditions the ability to advocate for rights to participate in and benefit from irrigation and other water uses (Meinzen-Dick 2014). However, women's ability to negotiate for their interests and preferences in the policy and community spaces is often limited - male engineers and farmers tend to dominate the design of schemes and other irrigation infrastructure and local, typically male, leaders set rules for participation and the distribution of resources (Udas 2014). For example, women working in the irrigation authority in Pakistan face significant constraints, including lack of access to their own separate toilets and harassment by male colleagues, which prevent women's meaningful participation in policy and planning decisions regarding water management (Shah and Memon 2014). At community level, local leadership may prevent women from participating in or speaking at irrigation scheme or water user group meetings, which reduces the influence of women farmers in local level governance (Lefore, Weight, and Mukhamedova 2017).

The way in which interventions are designed and implemented also influences the extent to which women can participate in and benefit from small-scale irrigation. More inclusive interventions take into consideration and aim to address the specific constraints and opportunities that women face in a particular context, such as lack of access to information about irrigation (Theis et al. 2018). On the other hand, gender-blind irrigation interventions can unintentionally introduce or exacerbate gender inequalities (Mitra and Rao 2019, Lefore, Weight, and Mukhamedova 2017, Nkhoma and Kayira 2016, van Koppen 2002). The gender sensitivity of irrigation and natural resource management programs depends, in part, on the perceptions about, as well as support and resources for, gender equity from decision makers from 
the national to local level, including men and women policymakers, irrigation engineers, project implementers, technocrats, among others (Dittoh, Snyder and Lefore 2015).

Even when the constraints that women face are taken into consideration in policy and program design, gender-sensitive policies may not be funded adequately or implemented at the local level. In this regard, the institutions and bodies that determine and allocate budgets are part of the opportunity structure. For example, in Malawi, national policy dictates that women should be included in the executive committees of water user associations (WUAs) and that 30 percent of plots in formal schemes should be allocated to women (Lefore, Weight, and Mukhamedova 2017). However, these quotas did little to increase women's meaningful participation in water management decisions at the local level, particularly in leadership roles within WUAs and women, particularly in patrilineal areas, still had difficulty accessing land and other resources, like inputs, to participate in and benefit from the scheme. A study in Ghana also suggested that a strong national narrative and official policy in support of gender equity did not translate to gender-sensitive programs and projects, because national agencies failed to allocate funding (Dittoh, Snyder and Lefore 2015).

While the opportunity structure often limits women's access to resources and agency, women that are able to adopt small-scale irrigation may benefit from a reduced work burden, greater participation in decision-making, increased control over income or productive resources, and expanded opportunities for community leadership and engagement. The extent to which women benefit directly from irrigation depends greatly on the context as well as the irrigation systems and technologies that are put in place and available to farmers. When women can adopt and benefit from irrigation practices and technologies, this can enable them to achieve the goals that they define for themselves. Often these goals go beyond aspirations for women's own lives to include well-being goals for other family or community memberssuch as putting children through school, ensuring the family's food security and nutrition, or helping others in the community (Bryan and Garner 2020, Meinzen-Dick et al. 2019). 


\section{APPLICATION OF THE FRAMEWORK TO CASE STUDIES BY TYPE OF IRRIGATION}

By applying the framework to multiple case studies covering different contexts, and different systems and technologies for small-scale irrigation, this review explores how these dimensions influence the relationship with resources, agency, and achievements (or benefits). The use of the framework for analysis enables us to highlight how the opportunity structure influences women's ability to participate in and benefit from small-scale irrigation within various types of schemes or system, and across different technologies. Women's ability to adopt small-scale irrigation also depends on the type and scale of the irrigation system and technologies selected for small-scale irrigation. The characteristics of different systems and technologies determine which resources and what type of agency are needed for women to successfully adopt and benefit from irrigation. Note that the typology of small-scale irrigation systems used in this paper focuses on the scale of operation of the system (communal, household, or group), which follows the common typology used by governments, policymakers or investors. Alternative typologies of small-scale irrigation systems could be based on other characteristics of irrigation that also have implications for gender dynamics and women's empowerment, including governance arrangements, ownership or management of the systems, or source of investment.

Table 1: Types of Irrigation by Scale

\begin{tabular}{|l|l|}
\hline Type & Description \\
\hline Communal schemes & $\begin{array}{l}\text { Systems that largely draw water from surface water bodies (and in fewer cases, lift from } \\
\text { deep groundwater), and distribute it through built infrastructure, such as gravity canals, } \\
\text { to numerous smallholder farmers within an area. The system command area may be } \\
\text { large, but individual farmer plots are often small-scale. Distribution of water tends to be } \\
\text { uneven, whereby farmers located closer to the water source have easier access } \\
\text { (amount and schedule) to sufficient water, while those located towards the tail end of the } \\
\text { scheme infrastructure may not receive equal or adequate shares of water. Public } \\
\text { institutions with support from international finance institutions often provide funding for } \\
\text { and own infrastructure, whereas members of the scheme may own or rent land within } \\
\text { the command area and be expected to pay for operation and maintenance costs. } \\
\text { Scheme decisions (governance) related to water management are expected to be } \\
\text { collective by water users within the scheme. }\end{array}$ \\
\hline $\begin{array}{l}\text { Systems at household level or individual level involve smallholder farmers utilizing } \\
\text { practices (such as water harvesting) or affordable technologies (such as motorized or } \\
\text { manual pumps) to lift water. Farmers typically access and lift water from hand-dug wells } \\
\text { or boreholes, or access surface water bodies, distributing water on field by furrow, hose, }\end{array}$ \\
\hline
\end{tabular}




\begin{tabular}{|l|l|}
\hline \multirow{7}{*}{ Group-based } & $\begin{array}{l}\text { sprinkler, drip or manual method. Farmers control the timing and application of water to } \\
\text { relatively small, individually owned or rented plots. Investment is predominantly made by } \\
\text { individual farmers with own funds or informal or small-scale finance. Decisions on } \\
\text { investments, technologies, practices, or water resources are typically autonomous and } \\
\text { lack formal consultation or coordination with other members of the community or } \\
\text { watershed. }\end{array}$ \\
& $\begin{array}{l}\text { Group-based systems involve groups of smallholder farmers sharing low-cost } \\
\text { infrastructure, and/or irrigation technologies, jointly farming small-scale irrigated plots or } \\
\text { contiguous plots, and/or sharing or renting irrigation technologies. Water sources are } \\
\text { both surface and shallow groundwater and field distribution often furrow, hose, sprinkler, } \\
\text { drip, or manual method, such as buckets or watering can. Group-based systems pool } \\
\text { the costs and resources associated with investment, which are sometimes farmers' own } \\
\text { investments, but often promoted through development interventions (e.g. irrigated home } \\
\text { garden projects with groups of women). Group-based systems often fall outside formal } \\
\text { governance structures for water resources. }\end{array}$ \\
\hline
\end{tabular}

Source: Authors

\subsection{Communal Schemes for Small-Scale Irrigation}

The resources and agency that women need to participate in different irrigation systems varies by the scale of the system. As the scale of an irrigation scheme increases, more finance, infrastructure, and resources (including labor) are needed. Similarly, as the scale of irrigation activities increases, stronger property rights and specialized institutional arrangements - i.e. those requiring greater levels of collective action and coordination - are needed for sustainable, efficient and inclusive management of irrigation (Meinzen-Dick 2014). In larger, communal schemes, the scale of irrigation increases and the bargaining spaces (or "domains of interaction") move beyond the home to include community and policy spaces, which in turns requires distinct forms of agency in order for women to have the ability to negotiate for their needs and interests (Meinzen-Dick and Zwarteveen 1998). In addition, the benefits that women derive from larger irrigation systems may also vary from other types of systems. A research and monitoring and evaluation tool, called the Gender in Irrigation Learning and Improvement Tool (GILIT), was designed to enable projects to assess gender and access to resources, participation in management decisions, and the distribution of benefits within irrigation schemes and tested in Malawi, Uzbekistan, and India (Lefore, Weight, and Mukhamedova 2017, Padmaja et al. 2019). This sub-section reviews the results of these studies and others that look at issues of resources, agency, and benefits of communal irrigation schemes. 


\subsubsection{Resources}

Collective irrigation schemes involving numerous smallholder farmers require considerable investment in irrigation infrastructure, including the initial cost of infrastructure construction and continuous costs of operation, maintenance, and repair. The resources invested in communal irrigation schemes are often significant (Inocencio et al 2007), yet land and water resources within these schemes are often unevenly distributed to farmers in a community and within the scheme, particularly women farmers. For example, a study of the Bakolori Irrigation Scheme in Zamfara, Nigeria showed that women were rarely allocated land of their own and that when some women did access land in the scheme it was the poorest quality land, located far from the water source (Abubakar, Danjuma, and Mustapha. 2017). Even in contexts where women have land rights, such as in the Lake Chalwa Basin in Malawi, the development of irrigation schemes disrupted matrilineal power structures through which women had strong land and water rights — men were favored within the scheme and allocated plots near the water source (Nkhoma and Kayira 2016). In Uzbekistan, women farmers were excluded from formal irrigation schemes and the water user associations, despite the disproportionate role women farmers play in irrigated food production for national nutritional security (Lefore, Weight, and Mukhamedova 2017).

Labor is another critical resource for engaging in irrigated production. The labor requirements of communal schemes are often higher than household or group systems, because scheme investors and managers expect small farmers to contribute to construction, operation, and maintenance of the schemes, and in some countries, building feeder roads to link the scheme to the road network. However, across several cases, women are more constrained than men in providing labor in these schemes due to a heavy work burden and the time required to manage plots within the schemes (e.g. land preparation for efficient water distribution); and social norms often discourage women from performing required heavy labor tasks, such as canal cleaning, or performing tasks at night (Chancellor and O’Neill 1999a, Matshalaga 1999, Awulachew et al. 2005). Examining two different case studies of communal schemes — one in Argentina and one in Ethiopia-Imburgia (2019) finds that the technical properties of irrigation systems largely determine the corresponding physical work demand and that the manual labor input required for 
water distribution creates a barrier for women. In Nepal, farmers' labor contribution for maintenance of a system was not linked to the size of their irrigated land so the cost-benefit ratio for women who tended to farm smaller plots was much higher (Udas 2014). In Egypt, social perceptions about women's physical inability to perform irrigation activities, such as canal cleaning, often prevented them from renting irrigable land, participating in irrigation, and providing wage labor for irrigation (Najjar, Baruah, and El Garhi 2019).

\subsubsection{Agency}

Irrigation schemes that serve multiple farms require coordinating institutions, rules, and property rights to land, infrastructure, and water (Meinzen-Dick 2014). Women's ability to participate in and benefit from communal schemes, therefore, depends on their success in negotiating for their interests at the community level (in addition to the household level) (Meinzen-Dick and Zwarteveen 1998). Women and men often have different preferences for how irrigation schemes are designed and operated and what crops are grown with irrigation (Chancellor and O’Neill 1999a, Matshalaga 1999). Yet women tend to be at a disadvantage in shaping decisions about the design, operation, and management of irrigation schemes, given more limited levels of collective and instrumental agency (Lefore, Weight, and Mukhamedova 2017, Chancellor, Hasnip, and O’Neill 1999, Chancellor and O’Neill 1999a, Matshalaga 1999; Meinzen-Dick and Zwarteveen 1998). Formal and informal membership criteria for participating in water management organizations, such as land ownership and organizing processes that target male heads of household, tend to exclude women (Imburgia 2019, Lefore, Weight, and Mukhamedova 2017, Aarnoudse, Closas and Lefore 2017, Meinzen-Dick and Zwarteveen 1998). For example, in Uzbekistan, women are largely excluded from water user groups and water management decisions as they are less likely to be landowners (Lefore, Weight, and Mukhamedova 2017). A study from South Africa showed, however, that where women have active groups, their ability to negotiate collectively for their interests in the rehabilitation of a water scheme was greater than in communities without active women's groups (Chancellor and O’Neill 1999a). 
Other constraints also prevent women from participating in water user and other decision-making groups. For example, women were never consulted in scheme planning or management for the agricultural watershed project in the Bundelkhand region in Central India, where social norms prohibit women from attending meetings and speaking in front of men (Padmaja et al. 2019). Similarly, women's already heavy labor burden can prevent them from participating meaningfully in water user groups, particularly if the meetings are not conveniently located or are poorly timed (Meinzen-Dick and Zwarteveen 1998).

Women's lack of agency, especially their limited participation in water user groups and particularly, their participation as executives in water user groups and water management decisions means that they have less input in the allocation of resources within the scheme (including land and water resources) and less access to information that is shared during these meetings, such as information about the timing of irrigation turns (Padmaja et al. 2019, Lefore, Weight, and Mukhamedova 2017).

\subsubsection{Benefits}

Moreover, the benefits that women can acquire from participation in the scheme are more limited than men given the constraints to influencing the design, management, and operation of the scheme in a way that meets their needs and preferences. For one, women tend to prefer schemes are designed for multiple purposes, serving women's needs for both domestic and productive uses of water (Lefore, Weight and Mukhamedova 2017, Shah and Memon 2014). Developing multiple-use irrigation systems that also alleviate women's domestic labor burden is particularly important in male-dominated farming systems where women's ability to participate in and benefit from irrigation is minimal (van Koppen and Hussain 2007).

Moreover, women's lack of instrumental agency also limits their ability to participate in and benefit from communal schemes. Women are at a disadvantage when they do not participate in scheme management, for instance, if the scheme managers schedule women's irrigation turns at night (Imburgia, 2019, Najjar, Baruah, and El Garhi 2019, van Koppen and Hussain 2007, Awulachew et al. 2005). 
Participating in communal schemes also requires a certain level of mobility to operate and maintain the system, which is another limiting factor for women in many contexts (Najjar, Baruah, and El Garhi 2019, Ashrafi and Rahman 2014, van Koppen and Hussain 2007).

Because women are constrained in providing labor to operate and maintain the schemes, they may not be able to receive adequate shares of water and, therefore, do not gain the full benefits of irrigated production. Conversely, women often withdraw participation in the schemes when they provide labor input but don't directly receive the benefits from their participation (Lefore, Weight, and Mukhamedova 2017). A study from Malawi showed that women's lack of access to resources and agency, namely inputs, credit, and labor as well as greater market constraints and limited control over income decisions within the household, also led to lower benefits from participation in the irrigation scheme (ibid).

Women also may benefit less than men from communal schemes due to more strict rules about what the water may be used for. When women contribute less to the design of the schemes and setting rules for their operation, they may not have access to water to meet their domestic needs, or homestead gardens used for household vegetable production. Moreover, there may be restrictions about which crops can be grown with the irrigation water-decisions are often taken by public agencies or water user group executives that generally do not reflect women's crop preferences. For example, in Zimbabwe, farmers participating in irrigation schemes were not able to choose which crops they grew and monocropping across the scheme reduced the price that farmers received for their output (Matshalaga 1999). Women were at a disadvantage because they mainly produced less valuable crops for home consumption and had less influence in marketing committees (ibid). Especially where women play a large role in farming, their limited ability to participate in and benefit from irrigation reduces the productivity of the entire scheme (van Koppen and Hussain 2007).

\subsection{Household-Level Irrigation}

Recent research highlights the ongoing expansion and potential for small-scale irrigation at the household level to contribute to national irrigation development plans and to improvements in the 
livelihoods and food security situation of smallholder farmers (Namara et al. 2014, Woodhouse, et al. 2017, Xie et al. 2014, 2018). While much of the research on gender and irrigation has focused on communal schemes, recent research explores gender and irrigation dynamics within household-level systems. Within these systems, women's ability to participate in and benefit from small-scale irrigation depends more on the distribution of household resources, such as agricultural plots, and intra-household bargaining processes (Bryan and Garner 2020, Theis et al. 2018, Nigussie et al. 2017). Decisions about intra-household resource allocation and gender roles in agriculture, including irrigation activities, are still strongly influenced by the opportunity structure, notably factors such as inheritance laws, social norms, and institutions.

Numerous studies have examined the constraints to adopting small-scale irrigation at the household level. Constraints that are highlighted include poorly developed supply chains for irrigation technologies, lack of access to credit, high operational and maintenance costs of irrigation technologies or schemes, high output price risks for irrigated crops, lack of market access for irrigated crops, and lack of institutional support (e.g. access to information, extension, training, and other services) (Giordano and de Fraiture 2014; Namara et al. 2014). Other household characteristics are also cited as determinants of adoption of small-scale irrigation, such as age and education of the household head, access to family labor, access to off farm income, proximity to urban areas, and landholding size (Namara et al. 2014, Haile et al. under review), as well as lack of information about the price of pumps and how to use and maintain them (Colenbrander and van Koppen 2012).

Yet men and women within the same households do not face the same set of constraints and opportunities for adopting small-scale irrigation practices and technologies. While the above-mentioned determinants and constraints apply largely to both men and women farmers, these constraints tend to be more pronounced for women in many contexts, and women and other resource-poor farmers typically face additional hurdles to adopting small-scale irrigation, such as less access to land and to water for irrigation, less access to financial capital, restrictive social norms, lack of access to knowledge and training, and heavier work burdens at home (Bryan and Garner 2020, Imburgia 2019, Abubakar et al. 
2017, Nigussie et al. 2017, Giordano and de Fraiture 2014; Colenbrander and Van Koppen 2012, van Koppen, Hope, and Colenbrander 2012).

\subsubsection{Resources}

As with communal schemes, women face considerable resource constraints in adopting practices and technologies for small-scale irrigation. In particular, access to irrigable land is a critical constraint for many women to engage in household-level irrigation (Dittoh, Snyder and Lefore 2015). This is especially true in patrilineal societies where women only access land through their husbands (Bryan and Garner 2020, Imburgia 2019, van Koppen and Hussain 2007), but may also apply to matrilineal societies where women must access land through uncles or other male relatives.

While labor input to maintain and operate communal infrastructure is not relevant to householdlevel irrigation systems, adoption and profitability of irrigation at household level is linked to labor. Household-level irrigation often increases the labor requirements of agriculture, due to the expansion of the production calendar into the dry season, the increase in time spent weeding and preparing land, the need to build fences around irrigated dry season plots, and managing livestock in ways that keep them from invading irrigated areas, in addition to the time it takes to water crops using various methods. The labor requirements of household-level irrigation also vary by water source and type of technology used. For example, in Northern Ghana, hand dug wells in the riverbed required considerable investment of labor at the start of each dry season, while households located near small reservoirs had an easier time accessing water for irrigation (Bryan and Garner 2020). Women were perceived to be unable to dig the hand dug wells and were, therefore, more easily excluded from engaging in irrigation in communities where that was the only source of water (ibid). Decisions about irrigation technologies may also be influenced by labor availability. In Ethiopia, households with more adult women who could provide labor for irrigation were less likely to invest in labor-saving technologies, such as pumps for water lifting and conveyance (Hagos et al. 2017). 
Women also tend to have less access to information about household irrigation technologies, like pumps, and less access to financing to purchase them. For example, in Zambia, women have less access to formal financial services to purchase pumps (Colenbrander and van Koppen 2012). In Ethiopia, women were more constrained in accessing information about irrigation technologies, because women lacked cell phones and contact with extension agents and projects, and were therefore, not invited to meetings (Nigussie et al. 2017). Women in Malawi also had lower access to the technologies through which information about irrigated agronomy was shared, such as radios, or lacked access to radios at times when agricultural programs were aired; extension field days were also held far from the household and women lacked time and means to participate (Lefore, Weight, and Mukhamedova 2017).

Women also tend to have less access to and control over productive assets and other agricultural inputs that are needed to successfully adopt and sustain irrigated production activities (Peterman, Behrman, and Quisumbing 2011, Doss 2001, Doss and Morris 2001). Access to technologies for smallscale irrigation is one of the largest impediments to the expansion of small-scale irrigation at the household level in many parts of the world, particularly, sub-Saharan Africa. Many of the most profitable technologies require prohibitive cash outlay for smallholder producers and, therefore, pump owners tend to be wealthier men farmers (de Fraiture and Giordano 2014, Namara et al. 2014). Even in South Asia where small-scale irrigation technologies, like motorized pumps, expanded rapidly, irrigation equipment tends to be purchased and owned by larger farmers (de Fraiture and Giordano 2014). Women farmers tend to be even less likely to adopt new, mechanized irrigation technologies, like motorized pumps, but often provide the labor for manual watering with buckets (de Fraiture and Giordano 2014). Which technologies are available in local markets or promoted by government or NGO interventions also affects adoption patterns. Evidence shows that men and women prefer different technologies, but these preferred technologies face different supply chain constraints. If only men's preferences are considered in the design of irrigation technologies, and in establishing national importation and distribution regimes, then the options that are available in the marketplace may be less appealing to women. Furthermore, many private companies do not target women in their marketing and distribution strategies for pumps. 
One approach to household level irrigation is rental, which is a growing business model in many countries. For example, in Ghana, given that pumps are unaffordable for most smallholder farmers, only a few farmers own motorized pumps and rental arrangements are becoming common in some regions (Namara et al. 2014). Accessing the credit needed to rent irrigation equipment may be much more feasible for women who find purchasing a pump cost prohibitive. Even then, renting pumps is difficult for some farmers with lack of access to financial services. Farmers often have limited money at the start of the season to rent pumps or purchase fuel (ibid). To address that challenge, women farmers in Ghana interplant a continuous harvest crop, such as leafy greens, to cover rental or running costs throughout the dry season (Balana et al 2017). Similarly, it matters to what extent women can participate in and benefit from rental services. A study from Bangladesh shows that women were less likely to receive mechanization services or act as service providers, although they did play important administrative roles and did express interest in opportunities to become more engaged (Theis et al. 2019).

\subsubsection{Agency}

Women's ability to adopt and benefit from small-scale irrigation at the household level also depends on their agency — especially their ability to bargain for practices, technologies, and uses of irrigation that meet their needs and preferences. Despite having different preferences for technologies women tend to be less involved in the selection and adoption of technologies and equipment for irrigation as well as decisions about how irrigation is applied (Theis et al 2018, Namara et al 2014, Njuki et al. 2014, Nigussie et al. 2017). For example, in Tanzania, while some men and women decided jointly to purchase a pump, when they disagreed, the men made the final decision and, in some cases, men purchased pumps without consulting their wives (Njuki et al. 2014). Sales data from both countries indicated that women purchased less than 10 percent of treadle pumps sold (ibid).

Gendered patterns of uptake of particular technologies and the ways these technologies are applied reflect preferences within a given institutional environment in which gender norms and roles may limit the ways women can benefit from engaging in irrigated production. In particular, women's 
preferences for different technologies for small-scale irrigation are strongly influenced by several factors, including whether the technology is considered appropriate for women to use, how much control women have over the technology, how and where the technology is applied, and what benefits women derive from using the technology in terms of time savings, control over output, or other benefits (Theis et al. 2018, Njuki et al. 2014). For example, a study in Ethiopia found that women preferred solar pumps because they were installed near the homestead where they could be used for domestic purposes and watering livestock (Nigussie et al. 2017). Women's intrinsic agency, their ability to use small-scale irrigation in pursuit of their own goals and interests is critical in determining the degree to which they participate in and benefit directly from irrigation activities.

While not as essential as with communal irrigation schemes, women's collective agency can facilitate their participation in household-level irrigation by increasing women's access to information, resources such as credit, and even labor sharing arrangements. Furthermore, as more people autonomously adopt irrigation at the household level using individual wells or tapping into surface water bodies, the impact on other users in the watershed increases-women's collective agency becomes more important as farmers develop rules for managing water more sustainably, to ensure that these rules are equitable (Meinzen-Dick 2014).

\subsubsection{Benefits}

Because women' often have less decision-making authority over which practices and technologies for small-scale irrigation are adopted and how they are used and applied, their ability benefit directly from use of the technology, for example, in terms of control over the produce and income from irrigated production, tends to be more limited (Theis et al. 2018). In some cases, such as in Tanzania, women may contribute to irrigated production decisions and activities but when it comes time to sell the crops, husbands dominate marketing, sales, and control over income (ibid). However, when women are able to engage in irrigation in ways that they prefer, such as on plots or crops that they control, there is some evidence that they can benefit directly and even increase their own agency through greater control 
over the output and income from the crops that they produce (Bryan and Garner 2020, Nigussie et al. 2017, Njuki et al. 2014, Van Koppen, Hope, and Colenbrander 2012). In some cases, women are more likely to participate in agricultural decisions and control output from irrigated production compared to rainfed production (Van Koppen, Hope, and Colenbrander 2012). Some of the factors that influence the extent to which women benefit from small-scale irrigation are: whether women have control over decisions related to how the technology is used, the labor implications of the technology, whether the irrigation water can be used for multiple purposes, the location of the irrigated plot and whether it is managed by women, and the types of crops grown on the plot.

The evidence suggests that men dominate irrigation with mechanized technologies because of social norms about ownership of agricultural machinery, and because the potential to reap greater benefits from irrigation increases with relatively newer technology (Bryan and Garner 2020; Theis et al 2017). For example, in Northern Ghana, even when women were in small groups that received access to a motor pump, pumps were considered major assets and, therefore, owned by their husbands, who then tended to take over irrigation activities (Bryan and Garner et al. 2020; Theis et al 2018). In Kenya and Tanzania, among households that adopted a treadle pump, men continued to make most of the major decisions on crop choices and income use (Njuki et al. 2014). Similarly, in Kenya women reported that men had control over the pumps and rarely lent them to women (Njuki et al. 2014). In some contexts, women have less control over manually-operated pumps because it is considered culturally inappropriate for women to operate these technologies (Njuki et al. 2014, Chancellor and O’Neill 1999b).

Women, therefore, express preference for technologies that they are better able to control in terms of how it is applied and the benefits from its use (Nigussie et al. 2017). For example, women farmers in Ethiopia perceived an increase in their control over income relative to men when they used tractor with drip and rope and washer, while use of a diesel pump was less likely to change women's participation in expenditure decisions given that they are mainly used on plots planted with cash crops that men control (ibid). 
Women also prefer technologies that can be applied to plots or crops that they control, such as those located near the home, or garden plots that they manage. Women in Ethiopia and Benin, for example, expressed preference for solar pumps installed near the household given that the capacity of the pumps is well suited for small household garden plots over which they have greater control (Theis et al. 2018, Nigussie et al. 2017, Burney et al. 2010). Women in Lesotho found it more difficult to engage in irrigated production on plots located far from the household because it made childcare more difficult (Riley and Krogman 1993). Even male-dominated farming systems, where women face constraints to engaging in irrigated cash crop production, women often maintain home gardens or plots where they cultivate staple crops mainly for home consumption. For example, in India, women benefitted most from adopting drip kits on home garden plots that produced food for household consumption but also provided women with a means to earn additional income (Namara, Uphadya, and Nagar 2005).

Women are aware of the risk that men will take over production activities that they control if the crops become commercialized or too profitable. For example, in the Gambia, the introduction of irrigation led male community leaders to take over production of rice, a crop previously controlled women (von Braun and Webb 1989). In these cases, women may mediate their goals to focus more on meeting household food security objectives while taking advantage of opportunities to earn small amounts of income. For example, in Kenya, women's ability to manage income from irrigated crops depended mainly on the type of crop, the quantities in which it was sold and whether it was for cash only or cash and food (Njukie et al. 2014). In general, women tend to have more control over produce and income from food crops, such as leafy green vegetables, while men have more control over cash crops, such as tomatoes (Nigussie et al. 2017, Njukie et al. 2014). In both Ghana and Ethiopia, women were able to control income over crops continuously harvested and garnered smaller amounts of cash over time, whereas men controlled the income from 'lumpy' harvest crops that led to larger amounts of cash in a single sale (Theis et al. 2018). Because women are typically responsible for sourcing and preparing foods for their families, irrigated home gardens also offer benefits in terms of increasing the availability of nutritious foods for the 
family. A study of home garden production in Burkina Faso found that irrigation programs increased the production of fruits and vegetables, increased food security, and improved nutrition (Olney et al. 2015).

Small-scale irrigation technologies also have implications for the level of labor input requiredmore manual irrigation technologies, like watering with buckets or manually-operated pumps, do not save much time and may in fact increase women's time in agricultural production. More mechanized irrigation technologies, like motorized or solar pumps, save time and have the capacity to irrigate even greater areas of land. Studies suggest that both men and women farmer prefer irrigation technologies that relieve their labor burden. For example, a study from Ghana found that there was considerable disadoption of treadle pumps that were promoted by NGOs due to high labor requirements, drudgery, and the limitations in terms of irrigable area (Namara et al. 2014).

Given the labor implications of irrigation using different small-scale technologies, it matters who provides the labor for irrigated production using these different methods. In general, women tend to engage more in irrigation using manual watering methods, such as buckets, while men dominate irrigation with motorized, labor-saving pumps (Theis et al. 2018, Nigussie et al. 2017, De Fraiture and Giordano 2014, Van Koppen, Hope, and Colenbrander 2012). This suggests that irrigation tends to be a more laborintensive task for women, given relatively higher constraints to more mechanized technologies. Because women also have heavy domestic workloads, with responsibilities for managing other uses of water, irrigation systems that provide water for multiple purposes are preferable and can save women considerable time (Nigussie et al. 2017, van Koppen and Hussain 2007). For example, in Ethiopia, women tend to use the irrigation technologies for multiple purposes including livestock watering and domestic uses, while men use them strictly for irrigation (Nigussie et al. 2017).

Even when men dominate irrigated production decisions and output, and the direct benefits of irrigation skew towards men, women still acknowledge the indirect benefits for their household and families. Often the goals or achievements women define for themselves are not ones that directly benefit them but those that benefit others in their household or community, such as increased household income that is used to enroll children in school or help others in the community (Bryan and Garner 2020, 
Meinzen-Dick et al. 2019, Nigussie et al. 2017). For example, in Kenya and Tanzania, despite their low ownership of and control over pumps, women perceived household benefits from pump use, including improved food security and an increase in household assets (Njuki et al. 2014). In Ghana, women noted social status and ability to lend other people money as benefits of increased household income from irrigation (Abujaja and Odonkor 2016).

However, in some cases, where there are considerable constraints to women's engagement in irrigation and limited ability to reap direct benefits, women may rationally seek other pathways to pursue their own goals. Research from Northern Ghana suggests that even when men take over irrigation activities with the introduction of new technologies, women are relieved to be free from the drudgery of irrigation and able to devote more time to other livelihood activities that may provide them with more direct benefits (Bryan and Garner 2020).

\subsection{Group-Based Irrigation}

Group-based approaches to irrigation can also be found, though few studies exist on gender or women farmers experiences in group irrigation. Given that motorized pumps and other technologies are costly for individual farmers to adopt, and also that weak markets make even affordable technologies difficult to access, small groups of households or individuals sometimes share the costs and efforts to invest in irrigation. Yet in other cases, non-profits or donors support small groups in an area to engage in irrigation.

\subsubsection{Resources}

Shared or group-based arrangements can address other resource constraints to engaging in small-scale irrigation, such as accessing land and labor. A case study from Lesotho suggests that irrigation through groups reduces time women spend irrigating and makes it easier to use and troubleshoot any problems that arise with the technology (Riley and Krogman 1993). In some cases, working together in groups on may facilitate women's access to jointly managed areas of land for irrigated production. While not focused on changes in women's access to land, a study from Benin suggests that women can effectively engage in small-scale irrigation by working together in groups on shared plots of land (Alaofe et al. 
2016). This intervention installed solar pumps and drip kits on vegetable garden plots that were subdivided and managed by groups of 30-35 women farmers, enabling them to increase access to nutritious foods and income. (ibid).

\subsubsection{Agency}

Sharing of household-level technologies like pumps or irrigation infrastructure like boreholes requires more collective agency than purchasing a pump for personal household use. What matters then is the extent to which can women participate in these shared arrangements. In Ghana, where small groups of men and women farmers gained access to motor pumps (some single sex and some mixed groups), women in groups that received the pump still generally considered their husbands to be the owners of the pump and let them decide how it was used (Bryan and Garner 2020). However, not all group members had equal access to the pump — some farmers who could afford to repay the bulk of the loan (typically men) had more control over how the pump was allocated to others in the group (ibid).

\subsubsection{Benefits}

Addressing only some factors of inequity in a small group system is insufficient to achieve positive outcomes for women. In Malawi, women had agency in the plot allocation process and in choosing the crop for their plots, but they felt little control over benefits because they did not participate in the marketing and usually did not know how much revenue had been generated (Lefore, Weight, and Mukhamedova 2017).

Yet other studies have shown that targeting women's groups makes it easier for them to participate in and retain the benefits from small-scale irrigation. For example, a solar garden intervention in Benin increased the number of women engaging in fruit and vegetable production and increased the variety of fruits and vegetables produced and consumed by the members of the women's groups (Alaofe et al. 2016). Women in farmer groups that gained access to irrigation also increased their income and allocated more income to food purchases, health care and education suggesting considerable gains in household nutritional status and increased decision-making authority of women (ibid). 
However, project design and how technology is deployed can also limit the benefits to women in group systems. In a project in Mali, solar pumps were used to lift groundwater into storage tanks for women to produce vegetables on small plots. However, labor constituted the largest cost because women were expected to manually take water from the tanks to distribute on their plots, and analysis showed the plots were too small to allow women to profit from surplus, women gained extremely low returns, and ultimately, many women chose to opt out of the project in the community (Gebrezgabher, Amewu, and Mul 2017).

Another observation from the literature on group-based irrigation is that men's groups are often self-financed, whereas women's group-based irrigation is often in the form or donor-funded projects. The source of funds has implications for influence over irrigation technology and use, as well as the aims. While men who invest can choose the technology, the crops and how to spend any profits, women may be engaged in projects aimed at production for direct consumption, as in general food security aims (WP on WUAs) or household nutrition (Gebrezgabher, Amewu and Mul 2017), rather than income. As one study on projects that target household gardens noted, very little is known about actual benefits for women (Merrey and Langan 2014). Women are also often engaged by donor-funded projects through village savings and loan projects, but most VSLAs do not save or lend enough to enable women to invest in labor-saving technologies, such as pumps, so have not addressed the credit constraints that women farmers face (Hagos et al. 2017). 


\section{ACHIEVING DEVELOPMENT OUTCOMES THROUGH WOMEN'S PARTICIPATION IN SMALL-SCALE IRRIGATION}

Regardless of the type of system or technology for small-scale irrigation, irrigation has long been recognized for its potential to contribute to agricultural intensification and farm profitability (Burney, Naylor, and Postel 2013, De Fraiture and Giordano, 2014, Giordano and de Fraiture 2014, Giordano et al. 2012, Xie et al. 2014, You et al., 2011). The discussion above, which is based on in-depth case studies, suggests that small-scale irrigation may also contribute to women's empowerment to the extent that constraints related to women's access to resources and lack of agency are overcome. Apart from these potential benefits for women, more research is emerging that documents the benefits of small-scale irrigation for other development outcomes, such as increasing food and nutrition security. Many of the quantitative studies provide additional evidence for the experiences of women and men farmers documented in the case studies.

Analysis suggests that irrigation interventions may influence nutrition outcomes along the same pathways as broader agricultural interventions - namely through changes in production outcomes and income - but also in more specific ways, such as changes in water supply, sanitation, and hygiene (Domènech 2015, Passarelli et al. 2018). Irrigation affects agricultural production outcomes by broadening the range of crops that farmers can cultivate, including crops that also have higher nutritional value, and increasing the diversity of crops produced (Alaofè et al. 2016; Burney et al. 2013; De Fraiture and Giordano 2014; Passarelli et al. 2018). Small-scale irrigation also affects the availability and stability of food supply by enabling more cropping seasons, including during dry periods (Aseyehegn, Yirga, and Rajan 2012), and by reducing the risks of rainfed production (Fox and Rockström 2003; Oweis and Hachum 2006). Reducing the risks of rainfed production in turn, may reduce encourage more investments in agricultural production (Abay et al. 2021).

Small-scale irrigation also has the potential to influence nutritional outcomes through an income pathway. Irrigation either introduces the production or increases the yields and quality of high-value crops, which can increase farm income through the sale of surplus produce (Burney and Naylor 2012; 
Passarelli et al. 2018). The income gained may be used to increase spending on nutritious foods, health care, and education (Alaofè et al. 2016; Burney and Naylor 2012). Irrigation can also expand employment opportunities for other households are not directly engaged in irrigated production (Namara et al. 2011). Irrigation may contribute to changes in the WASH environment affecting health risks, health status, and utilization of nutrients from food depending on the water source and irrigation system in place. On the positive side, irrigation can improve household access to water for hygienic and other domestic purposes, when multiple uses are considered in the design of the irrigation system. A study from Pakistan found that the use of irrigation water for domestic purposes reduced the incidence of diarrhea, thereby, improving the nutritional status of children (van der Hoek, Feenstra, and Konradsen, 2002). However, in some cases, the quality of irrigation water may not be appropriate for human consumption and irrigation may increase health risks, if not properly managed, through an increase in vector-borne diseases (Keiser et al. 2005). Irrigation may also increase runoff of agricultural chemicals, such as fertilizers and pesticides, which can affect water quality and human health (Mateo-Sagasta et al. 2017). In other words, irrigation is associated with some factors that could improve the WASH conditions of households and, therefore, women's empowerment and health, but those factors also require careful consideration to achieve positive outcomes.

As women have different preferences for how irrigation is applied and because they often pursue goals related to securing food and water for the household and children's well-being, changes in women's empowerment are likely to affect the pathways to these development outcomes in important ways. In term of the production pathway, because women have their own preferences for the types of crops that are planted and how these crops are used (e.g. for home consumption), interventions targeted to women for the purpose of intensifying irrigated home garden production have been shown to improve nutritional outcomes (Burney et al. 2010; Iannotti, Cunningham, and Ruel 2009; Olney et al. 2009, 2015). Similarly, in terms of the income pathway, women also have different preferences than men for how income is spent, prioritizing expenditures on food, schooling, and health care (Gillespie, Harris, and Kadiyala 2012; Meinzen-Dick et al. 2012). Again, studies suggest that when women control or have influence over 
income from irrigated production, they spend it in ways that improve family well-being (Alaofe et al. 2016, Njuki et al. 2014, Burney et al. 2010, Hagos, et al. 2017, Gebregziabher et al. 2017).

In terms of the water supply pathway, as women tend to prefer irrigation systems that provide water for multiple uses, such systems can save women's time and improve the WASH environment, depending on the quality of water and the way it is managed (Theis et al. 2018; van Koppen et al. 2009). Saving women's time can lead to greater investments of time in childcare (Burger and Esrey 1995; Cairncross and Cuff 1987; Diaz, Esrey, and Hurtado 1995; Miller and Urdinola 2010), which has positive health implications, such as reducing the incidence of diarrhea and improving nutritional outcomes of children (Pickering and Davis 2012), and improving hygiene practices (Aiello et al. 2008; Motarjemi et al. 1993). However, to the extent that irrigation increases women's time in agricultural production, this could lead to a reduction in the amount of time that mothers spend on household activities like cooking and caring for their children (Bénéfice and Simondon 1993; Brun, Reynaud, and Chevassus-Agnès 1989; Vaughan and Moore 1988), with potential negative consequences for nutrition.

Research for more than a decade has shown the high numbers of people who can potentially adopt and benefit from SSI, but those optimistic numbers include women farmers. If women are not given equitable access, and if women do not benefit and, therefore, do not sustain participation in irrigated production, then the numbers who actually benefit may be substantially lower than projections. Further, if equity in access is not achieved, and women do not take part in the expansion of irrigated production, then they are likely to lose longer-term access to natural resources (Lefore, et al 2019). In other words, not achieving equity has implications for women farmers in both the short- and long-term, as well as consequences for overall household nutrition and health. 


\section{CONCLUSIONS}

Research on gender and small-scale irrigation has grown over the past 20 years from a focus on women's participation in communal irrigation schemes to issues related to household-level irrigation. CGIAR research has contributed considerably to this body of literature including most recently through studies that highlight the importance of intra-household dynamics in determining the extent to which women participate in and benefit from small-scale irrigation. The focus on what goes on within households has also been possible through the application of research tools and data collection efforts that focus on intra-household dynamics, as opposed to earlier research that often compared male and female heads of household. Additional case studies that allow comparisons across countries and regions shed light on how the opportunity structure, and in particular gendered farming systems, influence the ways in which women can participate in and benefit from irrigation. However, less research has compared the nuances related to gender and irrigation across different types of small-scale irrigation systems and related technologies. This review paper aims to fill this gap by comparing and contrasting issues related to the distribution of resources, the ways in which women negotiate in and participate in irrigation decisions at multiple scales, and the benefits they are able to achieve under different irrigation systems, with different irrigation technologies, and under different social contexts.

Gender analysis is needed to inform the development of irrigation systems and programs to shape how small-scale irrigation technologies spread, such that these interventions take into consideration the opportunity structure within which women engage in irrigated production, the specific challenges related to the scale of the intervention, and the types of technologies promoted or available in the broader market. These factors strongly influence women's access to productive resources, the type of agency needed for women's active participation, and the benefits that women can accrue. While gender-responsive design could help to avoid creating new or worsening existing gender disparities, it may not guarantee gender equality in scheme operations, since schemes typically reflect "existing social relations in power" that have historically favored men (Lefore, Weight, and Mukhamedova 2017, World Bank 2014). 
Under communal schemes women's collective agency is essential for women to participate in the design, operation, and management of the scheme in ways that benefit them. Once schemes are designed, it becomes difficult to retroactively redistribute the resources and benefits within the scheme in ways that benefit women (Chancellor and O'Neill 1999a). Women in dual-farming systems have more opportunities to negotiate for land and water resources from the scheme and control the benefits from engaging in irrigated production but still face considerable constraints. In male-dominated farming systems, where women have few opportunities to participate meaningfully in irrigation, women may benefit most from the development of multiple use systems through which they may increase their access to domestic water (van Koppen and Hussain 2007). Negotiating for these benefits still requires some level of collective agency so that women may participate in decisions related to the design and operation of the schemes. External actors, such as governments or NGOs, may play a role in more equitable development of communal schemes, by allocating plots within the scheme to women or groups of women and supporting women's meaningful participation in water management groups.

With household-level irrigation, intra-household bargaining is essential for women to negotiate for access to land, water, and other resources. However, their ability to bargain for their own needs and preferences is still strongly influenced by social norms and other factors within the opportunity structure, such as the type of farming system and their expected roles within it. Here, the types of technologies that are available for small-scale irrigation and the extent to which women can use them in ways that they prefer become more important for determining the benefits women are able to achieve through smallscale irrigation. Interventions that facilitate the expansion of small-scale irrigation at the household level should consider the appropriateness of the technologies being promoted for women's needs and the particular constraints women face to controlling the technologies and reaping the benefits from their use.

There is still very little research about the constraints and opportunities for women to benefit through small-scale irrigation arrangements that fall somewhere between communal and household schemes. These arrangements, such as shared or group-based arrangements or even rental arrangements between a group of farmers, may become increasingly important as they demonstrate potential to sustainably reach 
and scale irrigation to more resource-poor smallholder farmers. Moreover, targeting groups of women may make it easier for them to collectively engage in small-scale irrigation activities as some programs have already demonstrated (Alaofe et al. 2016). More research is needed on these types of arrangements to ensure that they are scaled in a gender-sensitive way that enables women to participate in and benefit from irrigation including in both irrigated production and the provision of irrigation services.

Moreover, while this synthesis groups case studies by the scale of small-scale irrigation system, the relationship between other dimensions of small-scale irrigation systems and gendered outcomes needs further exploration. These dimensions include different modalities and approaches to delivering smallscale irrigation interventions and how these different approaches shape the distribution of benefits to men and women farmers. For example, demand-driven approaches may exclude women, because they often lack the resources needed for initial investment in irrigation equipment, while project-based approaches may more successfully reach and benefit women. Many projects are currently targeting finance for irrigation through asset-based financing, yet these finance mechanisms will continue to exclude women until some of the factors discussed above are integrated into the credit scoring tools. Another dimension that requires further analysis relates to how different ownership, operation, and governance arrangements of small-scale irrigation systems influence women's ability to participate in and benefit from irrigation.

It is also important to point out that when women participate in small-scale irrigation within these different modalities, there are potential benefits that go beyond those the women themselves gain, given women's social and livelihood roles in the household and community. In communal schemes women can contribute to the overall efficiency of the scheme by sustainably intensifying production on plots they manage. Women can also contribute to food security goals by producing nutritious crops, such as fruits and vegetables, for home consumption as well as for sale in local markets. The income women earn from engaging in irrigated production can also contribute to improve their family's and community's wellbeing. Therefore, gender-sensitive irrigation programs and investments can magnify the benefits of smallscale irrigation. 


\section{REFERENCES}

Abay, K.A., B. Koru, J. Chamberlin, and G. Berhane. 2021. Does rainfall variability explain low uptake of agricultural credit? Evidence from Ethiopia. European Review of Agricultural Economics. February 2021, pp. 1-26 doi:10.1093/erae/jbab013

Abubakar, S. A., M. N. Danjuma, and K. S. G. Mustapha. 2017. Constraints to Effective Participation of Women in Irrigation in Bakolori Irrigation Project, Zamfara, Nigeria. International Journal of Agricultural and Environmental Sciences, 2(3): 25-30.

Abujaja, A. M. and E. Odonkor. 2016. Gender-related small scale irrigation constraints, Ghana: Results of focus group discussions. ILSSI Technical Report (Ghana).

Ahmed, S. 2014. Challenging the Flow: Gendered Participation, Equity and Sustainability in Decentralized Water Governance in Gujarat. In Informing Water Policies in South Asia, Eds. A. Prakash, C. G. Goodrich, S. Singh, London: Routledge India.

Aiello, A. E., R. M. Coulborn, V. Perez, and E. L. Larson. 2008. Effect of Hand Hygiene on Infectious Disease Risk in the Community Setting: A Meta-Analysis. American Journal of Public Health, 98 (8): $1372-81$.

Alaofè, H., J. Burney, R. Naylor, and D. Taren. 2016. Solar-Powered Drip Irrigation Impacts on Crops Production Diversity and Dietary Diversity in Northern Benin. Food and Nutrition Bulletin, 37 (2): 164-75. doi:10.1177/0379572116639710.

Alsop, R., M. Bertelsen, and J. Holland. 2006. Empowerment in Practice: From Analysis to Implementation. Washington, DC: The World Bank.

Aarnoudse, E.; Closas, Alvar; Lefore, Nicole. 2017. Water user associations: a review of approaches and alternative management options for Sub-Saharan Africa. IWMI Working Paper 180. Colombo, Sri Lanka: International Water Management Institute (IWMI) 43p.

Aseyehegn, K., C. Yirga, and S. Rajan. 2012. Effect of Small-Scale Irrigation on the Income of Rural Farm Households: The Case of Laelay Maichew District, Central Tigray, Ethiopia. Journal of Agricultural Sciences, 7 (1): 43-57.

Ashrafi, S. A. and R. Rahman. 2014. An Attempt at Quantification of Women's Empowerment in SmallScale Water Resources Project. In Informing Water Policies in South Asia, Eds. Anjal Prakash, Chanda Gurung Goodrich, and Sreoshi Singh. London, United Kingdom: Taylor \& Francis Ltd.

Awulachew, S. B., D. J. Merrey, A. B. Kamara, B. Van Koppen, F. Penning de Vries, E. Boelee, and G. Makombe. 2005. Experiences and opportunities for promoting small-scale/micro irrigation and rainwater harvesting for food security in Ethiopia. IWMI Working Paper, 98. Colombo, Sri Lanka: IWMI. 
Balana, B., R. Appoh, Z. Adimassu, and N. Lefore. 2017. Profitability and Economic Feasibility Analysis of Small-Scale Irrigation Technologies in Zanlerigu and Bihinaayili, Northern Ghana. ILSSI Technical Report (Ghana).

Barker, R.; Molle, F. 2004. Evolution of irrigation in South and Southeast Asia. Comprehensive Assessment Research Report, 5. Colombo, Sri Lanka: Comprehensive Assessment Secretariat.

Beekman, W., G. J. Veldwisch, and A. Bolding. 2014. Identifying the potential for irrigation development in Mozambique: Capitalizing on the drivers behind farmer-led irrigation expansion. Physics and Chemistry of the Earth, 76-78: 54-63.

Bénéfice, E. and K. Simondon. 1993. Agricultural development and nutrition among rural populations: A case study of the middle valley in Senegal. Ecology of Food and Nutrition, 31(1-2): 45-66.

Bryan, E. and E. Garner. 2020. What does Empowerment Mean to Women in Northern Ghana? Insights from Research Around a Small-Scale Irrigation Intervention. IFPRI Discussion Paper, 1909. Washington, DC: International Food Policy Research Institute.

Brun, T., J. Reynaud, and S. Chevassus-Agnes. 1989. Food and Nutritional Impact of One Home Garden Project in Senegal. Ecology of Food and Nutrition, 23 (2): 91-108.

Burger, S. E., and S. A Esrey. 1995. Water and Sanitation: Health and Nutrition Benefits to Children.” In Child Growth and Nutrition in Developing Countries: Priorities for Action Ithaca, New York: Cornell University Press, 1995. 153-75. 153-74.

Burney, J. A., and R. L. Naylor. 2012. Smallholder Irrigation as a Poverty Alleviation Tool in SubSaharan Africa. World Development, 40 (1): 110-23. doi:10.1016/j.worlddev.2011.05.007.

Burney, J. A., R. L. Naylor, and S. L. Postel. 2013. The Case for Distributed Irrigation as a Development Priority in Sub-Saharan Africa. Proceedings of the National Academy of Sciences, 110 (31): 12513-17. doi:10.1073/pnas.1203597110.

Burney, J., L. Woltering, M. Burke, R. Naylor, and D. Pasternak. 2010. Solar-Powered Drip Irrigation Enhances Food Security in the Sudano-Sahel. Proceedings of the National Academy of Sciences, 107 (5): 1848-53. doi:10.1073/pnas.0909678107.

Cairncross, S. and J. L. Cuff. 1987. Water Use and Health in Mueda, Mozambique. Transactions of the Royal Society of Tropical Medicine and Hygiene, 81 (1): 51-54.

Chancellor, F. and D. O’Neill. 1999a. Gender-sensitive irrigation design: Gender issues in smallholder irrigation rehabilitation: Cases from South Africa. Report OD143 (Part 4). Wallingford, UK: H.R. Wallingford. Available at: https://assets.publishing.service.gov.uk/media/57a08d92e5274a31e0001932/R6876-od143pt4. 
Chancellor, F. and D. O’Neill. 1999b. Gender-sensitive irrigation design: Gender considerations relating to treadle pump adoption: Experiences from Zambia. Report OD143 (Part 3). Wallingford, UK: H.R. Wallingford. Available at: https://assets.publishing.service.gov.uk/media/57a08d92e5274a27b200190b/R6876-od143pt3.pdf

Chancellor, F., N. Hasnip, D. O’Neill. 1999. Gender-sensitive irrigation design: Guidance for smallholder irrigation development. Report OD143 (Part 1). Wallingford, UK: H.R. Wallingford. Available at https://assets.publishing.service.gov.uk/media/57a08d88e5274a27b20018dd/R6876-od143pt1.

Colenbrander, W. and B. van Koppen. 2012. Improving the supply chain of motor pumps to expand small-scale private irrigation in Zambia. IWMI Working Paper 154, Colombo, Sri Lanka: International Water Management Institute (IWMI). 22p. doi: 10.5337/2013.202.

Datta, R. and J. Kornberg. 2002. "Introduction: Empowerment and Disempowerment." In Women in Developing Countries: Assessing Strategies for Empowerment. Rekha Datta and Judith Kornberg, eds. Boulder and London: Lynne Rienner Publishers.

De Fraiture, C., and M. Giordano. 2014. Small Private Irrigation: A Thriving but Overlooked Sector. Agricultural Water Management, 131: 167-74. doi:10.1016/j.agwat.2013.07.005.

Deshmukh-Ranadive, J. (2005) “Gender, Power, and Empowerment: An Analysis of Household and Family Dynamics," In Measuring Empowerment: Cross-Disciplinary Perspectives. Deepa Narayan, ed. Washington, DC: The World Bank.

Diaz, E., S. A. Esrey, and E. Hurtado. 1995. Social and Biological Impact Following the Introduction of Household Water in Rural Guatemala. Ottowa, Ontario, Canada: International Development Research Center.

Dittoh, S., K. Snyder, and N. Lefore. 2015. Gender policies and implementation in agriculture, natural resources and poverty reduction: Case study of Ghana's Upper East Region. Colombo, Sri Lanka: International Water Management Institute. CGIAR Research Program on Water, Land and Ecosystems. Research for Development Learning Series. http://www.iwmi.cgiar.org/Publications/wle/r4d/wle_research_for_development-learning_series3.pdf

Djurfeldt, A. A., E. Hillbom, W. O. Mulwafu, P. Mvula, and G. Djurfeldt. 2018. "The family farms together, the decisions, however, are made by the man" - Matrilineal land tenure systems, welfare and decision making in rural Malawi, Land Use Policy, 70: 601-610.

Domènech, L. 2015. Improving Irrigation Access to Combat Food Insecurity and Undernutrition: A Review. Global Food Security, 6: 24-33. doi:10.1016/j.gfs.2015.09.001.

Doss, C. R. 2001. "Designing Agricultural Technology for African Women Farmers: Lessons from 25 Years of Experience.” World Development 29 (12): 2075-2092. 
Doss, C. R., and M. L. Morris. 2001. "How Does Gender Affect the Adoption of Agricultural Innovations? The Case of Improved Maize Technology in Ghana.” Agricultural Economics 25 (1): $27-39$.

Fox, P., and J. Rockström. 2003. Supplemental Irrigation for Dry-Spell Mitigation of Rainfed Agriculture in the Sahel. Agricultural Water Management, 61 (1): 29-50. doi:10.1016/S0378-3774 (03)00008-8.

Gebrezgabher, S., S. Amewu, and M. Mul. 2017. Assessment of Business Cases for Agricultural Water Management Interventions in Africa. Project Report. International Water Management Institute, Accra, Ghana.

Gebregziabher, G., F. Hagos, N. Lefore, and A. Haileslassie. 2017. Analysis of poverty impacts of household level water lifting irrigation technologies. ILSSI technical report (Ethiopia).

Gillespie, S., J. Harris, and S. Kadiyala. 2012. The Agriculture-Nutrition Disconnect in India: What Do We Know? IFPRI Discussion Paper 1187, International Food Policy Research Institute, Washington, DC.

Giordano, M., and C. de Fraiture. 2014. Small Private Irrigation: Enhancing Benefits and Managing Trade-Offs. Agricultural Water Management, 131: 175-82. doi:10.1016/j.agwat.2013.07.003.

Hagos, F., A. Mulugeta, T. Erkossa, S. Langan, N. Lefore and Y. Abebe. 2017. Poverty Profiles and Nutritional Outcomes of Using Spate Irrigation in Ethiopia. Irrigation and Drainage, 66: 577-588. http://onlinelibrary.wiley.com/doi/10.1002/ird.2117/full

Hagos, F., G. Gebregziabher, N. Lefore, and A. Haileslassie. 2017. Credit access and adoption of irrigation technologies by smallholder farmers: Evidence from Ethiopia. ILSSI Technical Report (Ethiopia).

Haile, B., D. K. Mekonnen, J. Choufani, C. Ringler, E. Bryan. Unpublished. Hierarchical modelling of the constraints to irrigation adoption in Ghana, Ethiopia, and Tanzania.

Iannotti, L., K. Cunningham, and M. Ruel. 2009. Improving Diet Quality and Micronutrient Nutrition: Homestead Food Production in Bangladesh. IFPRI Discussion Paper 928, International Food Policy Research Institute, Washington, DC. doi:10.1037/0003-066X.55.5.469.

Imburgia, L. 2019. Irrigation and equality: An integrative gender-analytical approach to water governance with examples from Ethiopia and Argentina. Water Alternatives, 12(2): 571-58.

Inocencio, A., Kikuchi, M., Tonasaki, M., Maruyama, A., Merrey, D., Sally, H. 2007. Costs and Performance of Irrigation Project: A Comparison of sub-Saharan Africa and Other Developing Countries. 2007. IWMI Research Report 109. Available at: http://www.iwmi.cgiar.org/Publications/IWMI_Research_Reports/PDF/PUB109/RR109.pdf. 
Kabeer, N. 1999. Resources, Agency, Achievements: Reflections on the Measurement of Women's Empowerment. Development and Change, 30: 435-464.

Keiser, J., M. Caldas de Castro, M. F. Maltese, R. Bos, M. Tanner, B. H. Singer, and J. Utzinger. 2005. Effect of Irrigation and Large Dams on the Burden of Malaria on a Global and Regional Scale. American Journal of Tropical Medicine and Hygiene, 72 (4): 392-406.

Kumar, N. and A. R. Quisumbing. 2015. Policy Reform toward Gender Equality in Ethiopia: Little by Little the Egg Begins to Walk. World Development 67: 406-423.

Lefore, N., M. Giordano, C. Ringler, and J. Barron. 2019. Sustainable and equitable growth in farmer-led irrigation in sub-Saharan Africa: What will it take? Water Alternatives 12(1): 156-168.

Lefore, N.; Weight, E.; Mukhamedova, N. 2017. Improving gender equity in irrigation: application of a tool to promote learning and performance in Malawi and Uzbekistan. Colombo, Sri Lanka: International Water Management Institute (IWMI). CGIAR Research Program on Water, Land and Ecosystems (WLE). 31p. (WLE Research for Development (R4D) Learning Series 6). doi: $10.5337 / 2017.217$

Malabo Montpellier Panel. 2018. Mechanized: Transforming Africa's agriculture value chains. Dakar, Senegal: International Food Policy Research Institute (IFPRI) and Malabo Montpellier Panel. http://ebrary.ifpri.org/cdm/ref/collection/p15738coll2/id/132766

Mason, K. O. 2005. Measuring Women's Empowerment: Learning from Cross-National Research. In Measuring Empowerment: Cross-Disciplinary Perspectives. Deepa Narayan, ed. Washington, DC: The World Bank.

Mateo-Sagasta, Javier, S. M. Zadeh, H. Turral and J. Burke. Water pollution from agriculture: a global review. Rome and Colombo: Food and Agriculture Organization and International Water Management Institute, 2017

Matshalaga, M. 1999. Gender-sensitive irrigation design: Consultation on gender issues in smallholder irrigation. Report OD143 (Part 6). Wallingford, UK: H.R. Wallingford. Available at: https://assets.publishing.service.gov.uk/media/57a08d91ed915d3cfd001ad8/R6876-od143pt6.pdf

Mensah, H. and B. Ibrahim. 2018. Perceptions of Male and Female in Collaborative Process at Weija Irrigation Scheme of Ghana. Journal of Advanced Agricultural Technologies, 5(2): 159-165.

Meinzen-Dick, R. S., D. Rubin, M. Elias, A. A. Mulema, and E. Myers. 2019. Women's Empowerment in Agriculture: Lessons from Qualitative Research. IFPRI Discussion Paper 1797. Washington, DC: International Food Policy Research Institute.

Meinzen-Dick, R. 2014. Property rights and sustainable irrigation: A developing country perspective. Agricultural Water Management, 145: 23-31. 
Meinzen-Dick, R., J. A. Behrman, P. Menon, and A. Quisumbing. 2012. "Gender: A Key Dimension Linking Agricultural Programs to Improved Nutrition and Health.” In Reshaping Agriculture for Nutrition and Health: 2020 Conference Book, edited by S. Fan and R. Pandya-Lorch, 135-44. Washington, DC: International Food Policy Research Institute. http://www.ifpri.org/sites/default/files/publications/oc69ch16.pdf.

Meinzen-Dick, R. and M. Zwarteveen 1998. Gendered participation in water management: Issues and illustrations from water users' associations in South Asia. Agriculture and Human Values, 15: $337-345$.

Merrey, D., and S. Langan. 2014. Review Paper on 'Garden Kits' in Africa: Lessons Learned and the Potential of Improved Water Management. IWMI Working Paper, 162. 10.5337/2015.202.

Miller, G., and B. P. Urdinola. 2010. Cyclicality, Mortality, and the Value of Time: The Case of Coffee Price Fluctuations and Child Survival in Colombia. Journal of Political Economy, 118 (1): $113-$ 55.

Mitra, A. and Rao, N. 2019. Gender, water, and nutrition in India: An intersectional perspective. Water Alternatives, 12(1): 169-191.

Mosedale, S. 2005. Assessing Women's Empowerment: Towards a Conceptual Framework. Journal of International Development, 17(2).

Motarjemi, Y., F. Käferstein, G. Moy, and F. Quevedo. 1993. Contaminated Weaning Food: A Major Risk Factor for Diarrhoea and Associated Malnutrition. Bulletin of the World Health Organization, 71 (1): 79.

Najjar, D., B. Baruah, and A. El Garhi. 2019. Women, irrigation and social norms in Egypt: 'The more things change, the more they stay the same?' Water Policy, 21: 291-309.

Namara, R., L. Hope, E. Owusu, C. de Fraiture, and D. Owusu. 2014. Adoption patterns and constraints pertaining to small-scale water lifting technologies in Ghana. Agricultural Water Management, 131: 194-203. 10.1016/j.agwat.2013.08.023.

Namara, R. E., J. A. Awuni, B. Barry, M. Giordano, L. Hope, E. S. Owusu, and G. Forkuor. 2011. Smallholder Shallow Groundwater Irrigation Development in the Upper East Region of Ghana. IWMI Research Report 143(139). Colombo, Sri Lanka: International Water Management Research Institute. doi:10.5337/2011.214.

Namara, R. E., B. Upadhyay, and R. K. Nagar. 2005. Adoption and Impacts of Microirrigation Technologies: Empirical Results from Selected Localities of Maharashtra and Gujarat States of India. IWMI Research Report 93(30). Colombo, Sri Lanka: International Water Management Research Institute. 
Narayan, D. 2005. Conceptual Framework and Methodological Challenges. In Measuring Empowerment: Cross-Disciplinary Perspectives. Deepa Narayan, ed. Washington, DC: The World Bank.

Nangia, V., and T. Oweis. 2016. Supplemental Irrigation: A Promising Climate-resilience Practice for Sustainable Dryland Agriculture. In Innovations in Dryland Agriculture, Farooq, M. and Siddique, K. (Eds.) 549-64. Cham, Switzerland: Springer.

Nigussie, L., N. Lefore, P. Schmitter, and A. Nicol. 2017. Gender and water technologies: Water lifting for irrigation and multiple purposes in Ethiopia. Africa RISING Report. Addis Ababa: International Livestock Research Institute.

Njuki, J., E. Waithanji, B. Sakwa, J. Kariuki, E. Mukewa, and J. Ngige. 2014. A qualitative assessment of gender and irrigation technology in Kenya and Tanzania. Gender, Technology, and Development, 18(3): 303-340.

Nkhoma, B. and G. Kayira. 2016. Gender and power contestations over water use in irrigation schemes: Lessons from the lake Chilwa basin. Physics and Chemistry of the Earth, 92: 79-84.

Nussbaum, M. C. 2000. Women and Human Development: The Capabilities Approach. Cambridge, UK: Cambridge University Press.

Olney, D. K., A. Pedehombga, M. T. Ruel, and A. Dillon. 2015. A 2-Year Integrated Agriculture and Nutrition and Health Behavior Change Communication Program Targeted to Women in Burkina Faso Reduces Anemia, Wasting, and Diarrhea in Children 3-12.9 Months of Age at Baseline: A Cluster-Randomized Controlled Trial.” Journal of Nutrition, 145 (6): 1317-24. doi:10.3945/jn.114.203539.

Olney, D. K., A. Talukder, L. L. Iannotti, M. T. Ruel, and V. Quinn. 2009. Assessing Impact and Impact Pathways of a Homestead Food Production Program on Household and Child Nutrition in Cambodia. Food and Nutrition Bulletin, 30 (4): 355-69. doi:10.1177/156482650903000407.

Oweis, T., and A. Hachum. 2006. Water Harvesting and Supplemental Irrigation for Improved Water Productivity of Dry Farming Systems in West Asia and North Africa. Agricultural Water Management, 80 (1): 57-73. doi:10.1016/j.agwat.2005.07.004.

Padmaja et al. 2019. Gender- and social-inclusion approach in watershed project: Insights on gender norms and gender relations in Parasai-Sindh watershed, India. A mixed-methods Gender study on the ICRISAT-CAFRI Project "Enhancing Groundwater Recharge and Water Use Efficiency in SAT Region through Watershed Interventions - Parasai-Sindh Watershed, Jhansi.”

Passarelli, S., D. Mekonnen, E. Bryan, and C. Ringler. 2018. Evaluating the Pathways from Small-Scale Irrigation to Dietary Diversity: Evidence from Ethiopia and Tanzania. Food Security, 10 (4): 981-97. doi:10.1007/s12571-018-0812-5. 
Peterman, A., J. Behrman, and A. R. Quisumbing. 2011. A review of empirical evidence on gender differences in non-land agricultural inputs, technology, and services in developing countries. ESA Working Paper No. 11-11.

Peterman, A., J. Behrman, and A. R. Quisumbing. 2014. A Review of Empirical Evidence on Gender Differences in Nonland Agricultural Inputs, Technology, and Services in Developing Countries. In Gender in Agriculture: Closing the Knowledge Gap. A.R. Quisumbing, R. Meinzen-Dick, T. L. Raney, A. Croppenstedt, J. A. Behrman, and A. Peterman (Eds.): 145-186

Petesch, P., C. Smulovitz, and M. Walton. 2005. Evaluating Empowerment: A Framework with Cases from Latin America. In Measuring Empowerment: Cross-Disciplinary Perspectives. Deepa Narayan, ed. Washington, DC: The World Bank.

Pickering, A. J., and J. Davis. 2012. Freshwater Availability and Water Fetching Distance Affect Child Health in Sub-Saharan Africa. Environmental Science \& Technology, 46 (4): 2391-97.

Riley, P. J., and N. T. Krogman. 1993. Gender-Related Factors Influencing the Viability of Irrigation Projects in Lesotho. Journal of Asian and African Studies, 28 (3-4): 162-79.

Rowlands, J. 1997. Questioning Empowerment: Working with Women in Honduras. Oxfam: Oxfam Publications.

Shah, S. A. and N. A. Memon. 2014. Entering Male Domain and Challenging Stereotypes: A Case Study on Gender and Irrigation in Sindh, Pakistan. In Informing Water Policies in South Asia, Eds. Anjal Prakash, Chanda Gurung Goodrich, and Sreoshi Singh. London, United Kingdom: Taylor \& Francis Ltd.

Stern, N., J. J. Dehier, and F. Halsey Rogers. 2005. Growth and Empowerment: Making Development Happen. Cambridge and London: The MIT Press.

Theis, S., T. J. Krupnik, N. Sultana, S. U. Rahman, G. Seymour, and N. Abedin. 2019. Gender and agricultural mechanization: A mixed-methods exploration of the impacts of multi-crop reaperharvester service provision in Bangladesh. IFPRI Discussion Paper 1837. Washington, DC: International Food Policy Research Institute (IFPRI). https://doi.org/10.2499/p15738coll2.133260

Theis, S., N. Lefore, R. Meinzen-Dick, and E. Bryan. 2018. What Happens after Technology Adoption? Gendered Aspects of Small-Scale Irrigation in Ethiopia, Ghana, and Tanzania. Agriculture and Human Values 35, 3: 671-684.

Theis, S., R. Deribe Bekele, N. Lefore, R. Meinzen-Dick, and C. Ringler. 2018. Considering Gender when Promoting Small-Scale Irrigation Technologies: Guidance for Inclusive Irrigation Interventions. IFPRI-REACH Project Note, Washington, DC: International Food Policy Research Institute. 
Udas, P. B. 2014. Rethinking Gender Inclusion and Equity in Irrigation Policy: Insights from Nepal. In Informing Water Policies in South Asia, Eds. Anjal Prakash, Chanda Gurung Goodrich, and Sreoshi Singh. London, United Kingdom: Taylor \& Francis Ltd.

Van der Hoek, W., S. G. Feenstra and F. Konradsen. 2002. Availability of Irrigation Water for Domestic Use in Pakistan: Its Impact on Prevalence of Diarrhoea and Nutritional Status of Children. Journal of Health, Population and Nutrition, 20(1): 77-84.

van Koppen, B.; Hope, L.; Colenbrander, W. 2012. Gender aspects of small-scale private irrigation in Africa. IWMI Working Paper, 153. Colombo, Sri Lanka: International Water Management Institute (IWMI). 25p. doi: 10.5337/2013.201

van Koppen, B., S. Smits, P. Moriarty, F. Penning de Vries, M. Mikhail, and E. Boelee. 2009. Climbing the Water Ladder: Multiple-Use Water Services for Poverty Reduction. TP series 52. The Hague, The Netherlands: IRC International Water and Sanitation Centre and International Water Management Institute. 213 p.

van Koppen, B. and I. Hussain 2007. Gender and Irrigation: Overview of Issues and Options. Irrigation and Drainage, 56: 289-298.

Vaughan, M., and H. Moore. 1988. Health Nutrition and Agricultural Development in Northern Zambia. Social Science and Medicine, 27 (7): 743-45.

von Braun, J. and P. J. R. Webb. 1989. The Impact of New Crop Technology on the Agricultural Division of Labor in a West African Setting, Economic Development and Cultural Change, University of Chicago Press, 37(3): 513-534.

Woodhouse P., G. J. Veldwisch, J. P. Venot, D. Brockington, H. Komakech and A. Manjichi. 2017. African farmer-led irrigation development: reframing agricultural policy and investment? The Journal of Peasant Studies, 44:1, 213-233, DOI:10.1080/03066150.2016.1219719

Xie, H., N. Perez, W. Anderson, C. Ringler and L. You. 2018. Can Sub-Saharan Africa feed itself? The role of irrigation development in the region's drylands for food security, Water International, 43(6): 796-814, DOI:10.1080/02508060.2018.1516080

Xie, H., L. You, B. Wielgosz, and C. Ringler. 2014. Estimating the Potential for Expanding Smallholder Irrigation in Sub-Saharan Africa. Agricultural Water Management, 131: 183-93. doi:10.1016/j.agwat.2013.08.011.

You, L., C. Ringler, U. Wood-Sichra, R. Robertson, S. Wood, T. Zhu, G. Nelson, Z. Guo, and Y. Sun. 2011. What Is the Irrigation Potential for Africa? A Combined Biophysical and Socioeconomic Approach. Food Policy, 36 (6): 770-8. doi:10.1016/j.foodpol.2011.09.001. 


\section{ALL IFPRI DISCUSSION PAPERS}

All discussion papers are available here

They can be downloaded free of charge

INTERNATIONAL FOOD POLICY RESEARCH INSTITUTE

www.ifpri.org

IFPRI HEADQUARTERS

1201 Eye Street, NW

Washington, DC 20005 USA

Tel.: +1-202-862-5600

Fax: +1-202-862-5606

Email: ifpri@cgiar.org 